\title{
Pajanan Timbal Terhadap Tingkat Kecerdasan Anak
}

\author{
Marshela Arianty, Michelle Beatrice, Suci Wulandari \\ Program Studi S1 Kesehatan Masyarakat, Fakultas Ilmu Kesehatan \\ Universitas Pembangunan Nasional Veteran Jakarta
}

\begin{abstract}
Abstrak
Latar belakang: Keracunan timbal menyebabkan penyakit organ multisistemik dengan gejala non spesifik pada kelainan neurologis, seperti penurunan IQ (intelligence quotient), ketidakmampuan belajar, pertumbuhan yang lambat, hiperaktif, perilaku antisosial, pendengaran terganggu serta pada tingkat paparan yang tinggi dapat menyebabkan ADHD (Attention-Deficit/ Hyperactivity Disorder). Artikel ini bertujuan untuk mengetahui bahaya pajanan timbal terhadap tingkat kecerdasan anak.

Metode: Merupakan systematic review dengan sumber data penelitian ini berasal dari 6 jurnal elektronik (DOAJ, ScienceDirect, CDC, NCBI, Springer Link, Proqeust). Inklusi jurnal termasuk; publikasi kurang dari 20 tahun kebelakang, diutamakan jurnal internasional, jurnal keracunan timbal yang berhubungan dengan penurunan kecerdasan, dan jurnal dengan kadar timbal dalam darah $<10$ $\mu \mathrm{g} / \mathrm{dL}$. Didapatkan 29 jurnal yang terdiri dari 22 jurnal berbahasa Inggris dan 7 jurnal berbahasa Indonesia. Kata kunci yang digunakan yaitu keracunan timbal, lead exposure, lead poisoning, systematic review, children, Intelligent Quotient (IQ).

Hasil: Faktor yang signifikan pada penelitian ini, yaitu faktor lingkungan rumah dan pendidikan orangtua. Kadar timbal dengan penurunan IQ tertinggi dari empat negara yaitu di Negara Amerika dengan penurunan IQ tujuh kali lipat.

Kesimpulan: Dapat disimpulkan bahwa keracunan timbal dapat mempengaruhi kecerdasan. Adanya timbal dalam darah $\geq 5 \mu \mathrm{g} / \mathrm{dL}$ dapat menurunkan IQ sebesar $\geq 7,4$ kali.
\end{abstract}

Kata kunci: Anak, Darah, Kecerdasan, Pajanan timbal

\section{Lead Exposure To The Level Of Intelligence Children}

\begin{abstract}
Background: Lead poisoning causes multisystemic organ disease with non-specific symptoms of neurological disorders, such as decreased IQ (intelligence quotient), learning disabilities, slow growth, hyperactivity, antisocial behavior, impaired hearing and high levels of exposure can cause ADHD (Attention-Deficit / Hyperactivity Disorder). This article aimed to know the danger of lead exposure to the level of intelligence of children.

Method: This article is a systematic review with the source data of this research comes from 6 electronic journals (DOAJ, ScienceDirect, CDC, NCBI, Springer Link, Proqeust). Include journal entries; publication less than 20 years back, preferably international journals, lead poisoning journals related to decreased intelligence, and journals with blood lead levels $<10 \mu \mathrm{g} / \mathrm{dL}$. There are 29 journals consisting of 22 English-language journals and 7 Indonesian-language journals. Keywords used are lead poisoning, lead exposure, lead poisoning, systematic review, children, Intelligent Quotient (IQ).

Results: Significant factors in this study, namely poor environmental factors and parent education. Lead levels with the highest IQ decline from four countries namely in the United States with a sevenfold decrease in $I Q$.

Conclusion: It can be concluded that lead poisoning can affect intelligence. The presence of lead in blood $\geq 5 \mu \mathrm{g} / \mathrm{dL}$ can decrease IQ by $\geq 7.4$ times.
\end{abstract}

Keyword: Child, Blood, Intelligence, Lead exposure

\footnotetext{
Alamat Korespondensi:

Marshela Arianty

Fakultas Ilmu Kesehatan, Universitas Pembangunan

Nasional Veteran Jakarta, Jl. Raya Limo, Depok

Email: mmstimbalupnvj@gmail.com
} 


\section{PENDAHULUAN}

Keracunan timbal menyebabkan penyakit organ multisistemik dengan gejala non spesifik pada kelainan neurologis, seperti penurunan IQ (intelligence quotient), ketidakmampuan belajar, pertumbuhan yang lambat, hiperaktif, perilaku antisosial, pendengaran terganggu serta pada tingkat paparan yang tinggi dapat menyebabkan ADHD (Attention-Deficit/ Hyperactivity Disorder). Timbal mengganggu berbagai proses tubuh dan beracun bagi banyak organ dan masalah, termasuk sistem saraf pusat 2-4. Pencemaran timbal berkontribusi pada $0,2 \%$ kematian dan risiko umur hidup yang hilang akibat kecacatan (disability-adjusted life year) sebesar $0,6 \%$ di seluruh dunia. Secara global, $98 \%$ orang dewasa dan $99 \%$ anak-anak berisiko terpapar timbal baik di negara berpenghasilan tinggi maupun berpenghasilan rendah $^{5}$. Di Amerika terjadi peningkatan keracunan timbal pada anak-anak sebesar $7 \%$ dari tahun 2007 hingga 2011. Akibat naiknya identifikasi kasus pada daerah berisiko tinggi diantara populasi berisiko ${ }^{6}$. Di Cina, rata-rata kadar timbal dalam darah anak-anak $92,9 \mu \mathrm{g} / \mathrm{L}$ dan lebih dari $30 \%$ sampel memiliki kadar timbal lebih dari $100 \mu \mathrm{g} / \mathrm{L}$ dalam darah 7. Di Dehli dan Mumbai, India; $45 \%$ dan $50 \%$ anak-anak memiliki kadar $>10 \mu \mathrm{g} / \mathrm{dL}$ timbal dalam darah ${ }^{8}$. Di Indonesia, persentase kadar timbal dalam darah dari 5-10 $\mu \mathrm{g} / \mathrm{dL}$ mencapai $21,8 \% ; 10-20 \mu \mathrm{g} / \mathrm{dL}$ mencapai $11,2 \%$; dan $>20$ mencapai $6,5 \%$ di tahun 2004 .

Timbal dalam jangka waktu panjang dapat terakumulasi dalam tubuh karena proses eliminasinya yang lambat 1 . Efek yang terjadi terutama pada anak-anak adalah penurunan IQ (Intelligence Quotient). Penelitian Canfield menunjukkan bahwa setiap kenaikan $10 \mu \mathrm{g} / \mathrm{dL}$ timbal dalam darah berhubungan dengan penurunan 4,6 poin IQ $(p=0,004){ }^{10}$. Kenaikan kadar timbal dalam darah di atas $20 \mu \mathrm{g} / \mathrm{dl}$ dapat mengakibatkan penurunan IQ sebesar 25 poin. Studi kohort di New York menunjukkan setiap kenaikan konsentrasi timbal $10 \mu \mathrm{g} / \mathrm{dL}$ dalam darah akan menurunkan IQ anak sebesar 4,6 poin ${ }^{11}$. Studi yang berbeda pada negara yang sama juga menunjukan penurunan IQ anak sebesar 4,9 poin dengan konsentrasi timbal dalam darah 5$9,9 \mu \mathrm{g} / \mathrm{dL}$ 12. Pajanan timbal pada anak-anak Afrika-Amerika dari umur 4, 9 dan 11 tahun selama periode neonatal menunjukkan hubungan terbalik antara kadar timbal dalam darah dengan tingkat IQ anak ${ }^{12}$.

Emisi kendaraan bermotor merupakan sumber pajanan terbesar timbal, karena pembakaran yang tidak sempurna. Menurut Environment Project Agency, sekitar $25 \%$ logam berat timbal $(\mathrm{Pb})$ tetap berada dalam mesin dan $75 \%$ lainnya akan mencemari udara sebagai asap knalpot. Daerah lain yang juga dianggap sebagai sumber pajanan timbal yaitu perumahan tua dan lingkungan miskin ${ }^{13}$. Selain itu bahan pengemas, saluran air, alat-alat rumah tangga dan hiasan juga dianggap sebagai sumber pajanan timbal. Dalam bentuk oksida timbal digunakan sebagai pigmen/zat warna dalam industri kosmetik dan glace serta indusri keramik yang sebagian diantaranya digunakan dalam peralatan rumah tangga ${ }^{1}$. Timbal dalam makanan kaleng yang berasal dari patrian antara badan kaleng dengan tutupnya juga bisa menjadi sumber pajanan timbal $^{2}$. Formulasi cat dan mainan anak-anak juga dapat menjadi sumber pajanan. Mainan gigitan bayi yang umumnya terbuat dari karet dan plastik perlu diwaspadai akan kemungkinan adanya cemaran logam timbal ${ }^{14}$.

Anak kecil sangat rentan terhadap efek racun timbal dan mempengaruhi perkembangan otak serta sistem saraf ${ }^{5}$. Perkembangan otak pada usia anak-anak mempengaruhi status kecerdasan dimasa mendatang. Timbal dapat dengan mudah menembus selaput otak anak-anak karena masih dalam tahap perkembangan. Hal ini dapat memberikan efek buruk pada perkembangan kecerdasan anak-anak. Oleh karena itu, artikel ini menggunakan pendekatan systematic review bertujuan untuk mengetahui bahaya pajanan timbal terhadap tingkat kecerdasan anak.

\section{METODE}

Penelitian merupakan systematic review membahas bahaya pajanan timbal terhadap tingkat kecerdasan anak. Sumber data penelitian ini berasal dari jurnal elektronik meliputi Directory of Open Access Journals (DOAJ), ScienceDirect, Center for Disease Control and Prevention (CDC), National Center for Biotechnology Information (NCBI), Springer Link, dan Proqeust.

Jurnal diambil dari tahun 1993-2016 sebanyak 29 jurnal terdiri dari 22 jurnal berbahasa Inggris dan 7 jurnal berbahasa Indonesia. Kata kunci yang digunakan yaitu 
keracunan timbal, lead exposure, lead poisoning, systematic review, children, Intelligent Quotient (IQ).

Untuk memfilter jurnal yang ditinjau, digunakan kriteria seleksi jurnal yang digunakan sebagai bahan, sebagai berikut: jurnal keracunan timbal yang berhubungan dengan penurunan kecerdasan, jurnal dengan kadar timbal dalam darah $<10 \mu \mathrm{g} / \mathrm{dL}$, diutamakan jurnal berbahasa inggris, publikasi jurnal dari 15 tahun kebelakang.

\section{HASIL}

Penelitian pencemaran timbal terhadap tingkat intelegensi anak banyak diteliti di Amerika Serikat dan desain penelitian yang paling sering digunakan adalah cross-sectional. Jumlah sampel yang diteliti cukup beragam mulai dari 2 - 204. Sebagian besar penelitian menggunakan 13 sampai 147 literatur. Biomarker yang digunakan untuk identifikasi kadar timbal yaitu darah. Tingkat kecerdasan diukur menggunakan Test IQ maupun kuesioner.

Tabel 1. Gambaran Umum Penelitian Pajanan Timbal terhadap Kecerdasan Anak

\begin{tabular}{|c|c|c|c|c|c|c|c|}
\hline Peneliti & Negara & $\begin{array}{c}\text { Variabel } \\
\text { yang } \\
\text { diteliti }\end{array}$ & $\begin{array}{c}\text { Variabel } \\
\text { yang } \\
\text { signifikan }\end{array}$ & $\begin{array}{l}\text { Jumlah } \\
\text { sampel }\end{array}$ & $\begin{array}{c}\text { Desain } \\
\text { penelitian }\end{array}$ & $\begin{array}{c}\text { Jumlah } \\
\text { Kepustak } \\
\text { aan }\end{array}$ & Alat Ukur \\
\hline $\begin{array}{l}\text { Vivier, } \\
2008^{15}\end{array}$ & US & 6 & 2 & 204.746 & $\begin{array}{l}\text { Lead } \\
\text { Elimination } \\
\text { Surveillance } \\
\text { System } \\
\text { (LESS) }\end{array}$ & 21 & - \\
\hline $\begin{array}{l}\text { Budiyono, } \\
2016^{16}\end{array}$ & Indonesia & 6 & 1 & 129 & $\begin{array}{l}\text { Cross- } \\
\text { Sectional }\end{array}$ & 13 & $\begin{array}{l}\text { Sampel darah } \\
\text { dan rata-rata } \\
\text { prestasi belajar }\end{array}$ \\
\hline $\begin{array}{l}\text { Romli, } \\
2016^{17}\end{array}$ & Indonesia & 8 & 1 & 51 & $\begin{array}{l}\text { Cross- } \\
\text { Sectional }\end{array}$ & 21 & $\begin{array}{ll}\text { Interview } & \text { dan } \\
\text { observasi } & \end{array}$ \\
\hline $\begin{array}{l}\text { Ratnasari, } \\
2016^{18}\end{array}$ & Indonesia & 4 & 1 & 80 & $\begin{array}{l}\text { Cross- } \\
\text { Sectional }\end{array}$ & 24 & Kuesioner \\
\hline $\begin{array}{l}\text { Mazumdar } \\
, 2011^{10}\end{array}$ & USA & 2 & 1 & 249 & Kohort & 28 & Kuesioner \\
\hline $\begin{array}{l}\text { Daneshpar } \\
\text { var, } 2016^{3}\end{array}$ & Iran & 4 & 1 & 22 & $\begin{array}{l}\text { Systematic } \\
\text { Review }\end{array}$ & 34 & - \\
\hline $\begin{array}{l}\text { Lo, } 2010 \\
19\end{array}$ & Nigeria & 4 & 1 & 204 & $\begin{array}{l}\text { Cross- } \\
\text { sectional }\end{array}$ & 21 & Kuesioner \\
\hline $\begin{array}{l}\text { Rasoul, } \\
1989^{20}\end{array}$ & Mesir & 5 & 1 & 102 & $\begin{array}{l}\text { Cross- } \\
\text { sectional }\end{array}$ & 34 & - \\
\hline $\operatorname{Lin}_{21} 2011$ & Cina & 11 & 1 & 61 & $\begin{array}{l}\text { Cross- } \\
\text { sectional }\end{array}$ & 30 & Kuesioner \\
\hline $\mathrm{Li}, 2016^{22}$ & Cina & 17 & 1 & 34 & $\begin{array}{l}\text { Meta- } \\
\text { analysis }\end{array}$ & 79 & $\begin{array}{l}\text { MeSH (Medical } \\
\text { subject heading } \\
\text { terms) }\end{array}$ \\
\hline $\begin{array}{l}\text { Karrari, } \\
2012^{23}\end{array}$ & Iran & 5 & 1 & 332 & $\begin{array}{l}\text { Systematic } \\
\text { review }\end{array}$ & 147 & - \\
\hline $\begin{array}{l}\text { Graber, } \\
2010^{24}\end{array}$ & Uganda & 27 & 1 & 163 & $\begin{array}{l}\text { Cross- } \\
\text { sectional }\end{array}$ & 40 & Kuesioner \\
\hline $\begin{array}{l}\text { Liu, } \\
2013^{25}\end{array}$ & China & 3 & 1 & 1341 & Kohort & 65 & $\begin{array}{lr}\text { Tes IQ, } & \text { tes } \\
\text { standar } & \text { kota } \\
\text { pada } 3 & \text { mata } \\
\text { pelajaran utama }\end{array}$ \\
\hline
\end{tabular}




\begin{tabular}{|c|c|c|c|c|c|c|c|}
\hline Peneliti & Negara & $\begin{array}{l}\text { Variabel } \\
\text { yang } \\
\text { diteliti }\end{array}$ & $\begin{array}{l}\text { Variabel } \\
\text { yang } \\
\text { signifikan }\end{array}$ & $\begin{array}{l}\text { Jumlah } \\
\text { sampel }\end{array}$ & $\begin{array}{c}\text { Desain } \\
\text { penelitian }\end{array}$ & $\begin{array}{l}\text { Jumlah } \\
\text { Kepustak } \\
\text { aan }\end{array}$ & Alat Ukur \\
\hline $\begin{array}{l}\text { Chen, } \\
2005^{26}\end{array}$ & Boston & 1 & 1 & 780 & $\begin{array}{l}\text { Cross- } \\
\text { sectional }\end{array}$ & 28 & Tes IQ \\
\hline $\begin{array}{l}\text { Lewendon } \\
, 2001^{27}\end{array}$ & USA & 2 & 1 & $\begin{array}{l}69 \text { kasus } \\
\text { dan } 136 \\
\text { kontrol }\end{array}$ & Case Contol & 21 & $\begin{array}{l}\text { Graphite } \\
\text { furnace atomic } \\
\text { absorption }\end{array}$ \\
\hline $\begin{array}{l}\text { Shah, } \\
\text { Keneil K, } \\
2017^{28}\end{array}$ & $\begin{array}{l}\text { Flint, } \\
\text { Michigan }\end{array}$ & 2 & 1 & - & Descriptif & & Tabel BLL \\
\hline $\begin{array}{l}\text { Shuangxin } \\
\mathrm{g} \quad \text { Hou, } \\
2013^{4}\end{array}$ & China & 2 & 1 & 100 & $\begin{array}{l}\text { Original } \\
\text { Articel }\end{array}$ & 36 & $\begin{array}{l}\text { Survei } \\
\text { kuesioner; } \\
\text { analisis } \\
\text { pemisahan } \\
\text { potensiometri } \\
\text { diferensial } \\
\text { (DPSA); Skala } \\
\text { Pengembangan } \\
\text { Gesell; The } \\
\text { Achenbach } \\
\text { Child Behavior } \\
\text { Checklist } \\
\text { (CBCL) }\end{array}$ \\
\hline $\begin{array}{l}\text { Jusko, } \\
2008^{12}\end{array}$ & New York & 15 & 4 & 242 & $\begin{array}{l}\text { Studi } \\
\text { Prospektif }\end{array}$ & 48 & $\begin{array}{l}\text { HOME-SF dan } \\
\text { WPPSI-R IQ } \\
\text { score }\end{array}$ \\
\hline $\begin{array}{l}\text { Min, } \\
2009^{29}\end{array}$ & Cleveland & 21 & 1 & 278 & $\begin{array}{l}\text { Studi } \\
\text { longitudinal } \\
\text { prospective }\end{array}$ & 67 & $\begin{array}{l}\text { Sampel urin dan } \\
\text { WPPSI-R, } \\
\text { WISC-IV }\end{array}$ \\
\hline $\begin{array}{l}\text { Canfield, } \\
2003^{11}\end{array}$ & New York & 11 & 1 & 172 & Kohort & 50 & $\begin{array}{l}\text { Stanford-Binet } \\
\text { In- telligence } \\
\text { Scale, fourth } \\
\text { edition }\end{array}$ \\
\hline $\begin{array}{l}\text { Haven, } \\
2018^{30}\end{array}$ & Vietman & 7 & 3 & 311 & $\begin{array}{l}\text { Cross- } \\
\text { sectional }\end{array}$ & 27 & LeadTech $^{\mathrm{TM}}$ \\
\hline $\begin{array}{l}\text { Hou, } \\
2013^{4}\end{array}$ & China & 11 & 3 & 96 & Eksperimen & 36 & $\begin{array}{l}\text { Health } \\
\text { questionnaire } \\
\text { dan CBCL }\end{array}$ \\
\hline $\begin{array}{l}\text { Jain, } \\
2006^{8}\end{array}$ & India & 7 & 5 & 1.081 & $\begin{array}{l}\text { Cross- } \\
\text { sectional }\end{array}$ & 51 & Survei \\
\hline
\end{tabular}

Faktor risiko pajanan timbal antara lain faktor emisi kendaraan bermotor, perumahan tua, lingkungan miskin, peleburan aki bekas, saluran air yang tercemar, alat-alat rumah tangga, pendidikan orangtua, kegiatan industri, makanan kaleng, formulasi cat, mainan gigitan bayi, dan debu di rumah.
Faktor lingkungan rumah dan pendidikan orang tua merupakan faktor yang paling banyak diteliti. Jadi dapat disimpulkan bahwa lingkungan miskin dan pendidikan orangtua paling sering menjadi faktor pemicu pajanan timbal. 
Tabel 2. Faktor Risiko Pajanan Timbal

\begin{tabular}{|c|c|c|c|c|c|c|c|c|c|c|c|c|c|c|}
\hline Peneliti & $\begin{array}{c}\text { Perumahan } \\
\text { Tua }\end{array}$ & $\begin{array}{c}\text { Lingkungan } \\
\text { Rumah }\end{array}$ & $\begin{array}{l}\text { Obat \& } \\
\text { Minuman } \\
\text { Orangtua }\end{array}$ & $\begin{array}{l}\text { Peleburan } \\
\text { Aki Bekas }\end{array}$ & Akses Air & $\begin{array}{c}\text { Alat-Alat } \\
\text { Rumah } \\
\text { Tangga }\end{array}$ & Pola Asuh & $\begin{array}{l}\text { Pendidikan } \\
\text { Orangtua }\end{array}$ & Industri & Makanan & $\begin{array}{c}\text { Mainan } \\
\text { gigitan bayi }\end{array}$ & $\begin{array}{c}\text { Tingkat } \\
\text { Kecerdasan }\end{array}$ & $\begin{array}{l}\text { Polusi } \\
\text { Udara }\end{array}$ & Umur \\
\hline Vivier, $2008^{15}$ & $\mathrm{~V}(1,77)$ & $\mathrm{V}(1,64)$ & & & & & & & & & & & & \\
\hline Budiyono,2016 ${ }^{16}$ & & & & $\mathrm{~V}$ & & & & $\mathrm{~V}(3,02)$ & & & & & & \\
\hline Romli,2016 ${ }^{1 /}$ & & & & & & & & & & & & $\mathrm{V}$ & & \\
\hline Ratnasari, $2016^{18}$ & & & & & & & & & & & & $\mathrm{~V}$ & & \\
\hline Mazumdar, 2011 & & $\mathrm{~V}$ & & & & & & $\mathrm{~V}$ & & & & & & \\
\hline Daneshparvar, & & & & & & & & & $\mathrm{V}$ & & & & & \\
\hline Lo, $2010^{19}$ & & & & & & & & & & & & & $\mathrm{~V}$ & \\
\hline Rasoul, $1989^{20}$ & & $\mathrm{~V}$ & & & & & & & & & & & & \\
\hline Lin, $2011^{21}$ & & & & & & & & & & & & & $\mathrm{~V}$ & \\
\hline \multicolumn{15}{|l|}{$\mathrm{Li}, 2016^{22}$} \\
\hline Karrari, $2012^{23}$ & & $\mathrm{~V}$ & & & & & & & & & & & & \\
\hline Graber, $2010^{24}$ & & $\mathrm{~V}(0,80)$ & & & & & & & & & & & $\mathrm{V}(1,11)$ & \\
\hline Liu, $2013^{25}$ & $\mathrm{~V}$ & & & & & & & $\mathrm{~V}$ & & & & & & \\
\hline Chen, $2005^{26}$ & & $\mathrm{~V}$ & & & & & & $\mathrm{~V}$ & & & & & & \\
\hline Lewendon, $2001^{21}$ & & & & & $\mathrm{~V}$ & & & & & & & & & \\
\hline Shuangxing Hou, & & $\mathrm{V}$ & $\mathrm{V}$ & & & & & & & & $\mathrm{V}$ & & $\mathrm{V}$ & \\
\hline \multicolumn{15}{|l|}{\begin{tabular}{|l|} 
Jusko, $2008^{12}$ \\
\end{tabular}} \\
\hline \multicolumn{15}{|l|}{ Min, $2009^{29}$} \\
\hline Canfield, 2003 & & $\mathrm{V}$ & & & $\mathrm{V}$ & & & & & & & & & \\
\hline Haven, $2018 s^{30}$ & & $\mathrm{~V}(2,7)$ & & & $\mathrm{V}(3,6)$ & & & & & & & & & $\mathrm{V}(16,8)$ \\
\hline Hou, 2013 & & & & & & & $\mathrm{V}(1,26)$ & & & $\mathrm{V}(4,84)$ & & & $\mathrm{V}(2,98)$ & \\
\hline \begin{tabular}{|l|} 
Jain, 2006 \\
\end{tabular} & & $\mathrm{V}(2,6)$ & & & & & $\mathrm{V}(6,0)$ & & & & & & & $\mathrm{V}()$ \\
\hline Total & 2 & 10 & 1 & 1 & 3 & & 2 & 5 & 1 & 2 & 1 & 2 & & \\
\hline
\end{tabular}

Kadar timbal dengan penurunan IQ tertinggi dari empat negara yaitu di Negara
Amerika dengan kadar timbal 5 - 9,9 $\mu \mathrm{g} / \mathrm{dL}$ yang menyebabkan penurunan IQ 7,4 kali $^{11}$

\section{Grafik 1. Hubungan Kadar Timbal dengan Tingkat Kecerdasan}

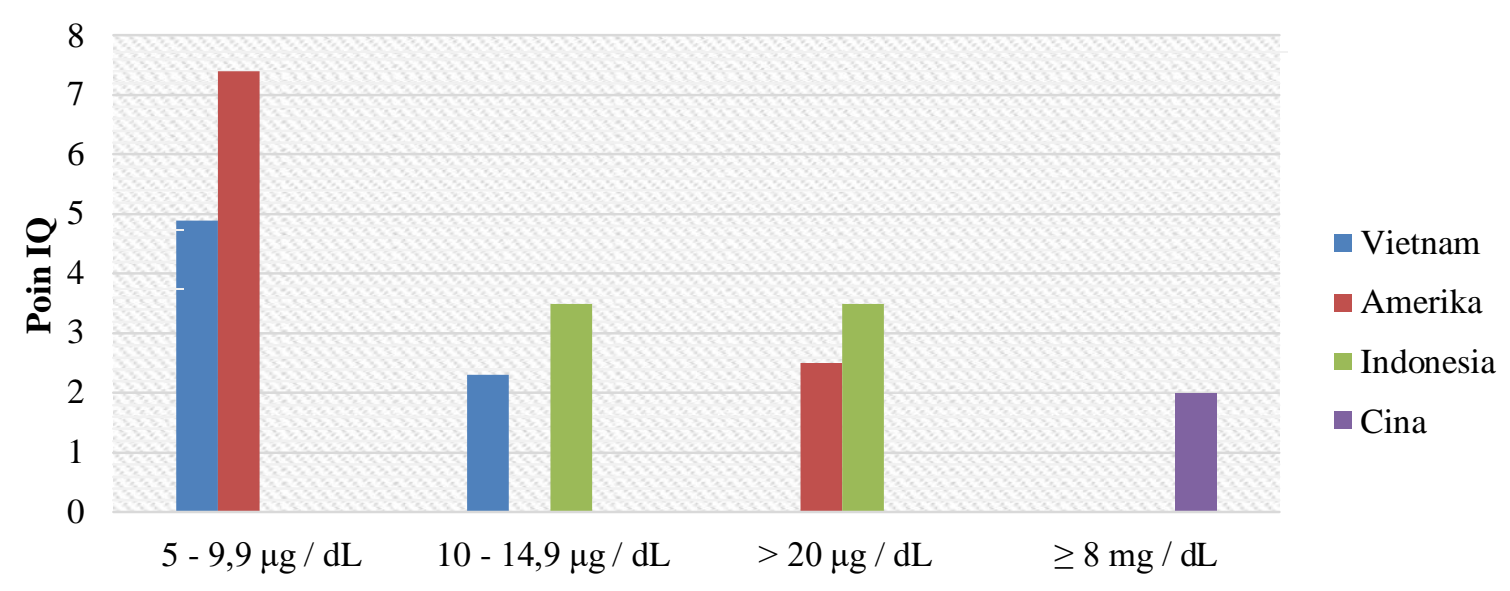

Kadar Timbal 
Berdasarkan daftar pustaka dari jurnal yang didapat, jurnal 10 tahun kebelakang baik dari dalam maupun luar negeri paling banyak digunakan sebagai daftar pustaka. Hal ini karena pajanan timbal paling banyak diteliti sekitar tahun 90-an. Sedangkan buku 10 tahun kebelakang menjadi sumber daftar pustaka yang paling sedikit digunakan, karena tidak banyak buku 10 tahun kebelakang yang menulis tentang pajanan timbal.

Tabel 3. Gambaran Distribusi Daftar Pustaka

\begin{tabular}{|c|c|c|c|c|c|c|c|}
\hline \multirow[b]{2}{*}{ Penelitian } & \multicolumn{2}{|l|}{ Buku } & \multicolumn{2}{|l|}{ Jurnal } & \multicolumn{2}{|l|}{ Lain-lain } & \multirow[b]{2}{*}{ Total } \\
\hline & $\leq 10$ & $>10$ & $\leq 10$ & $>10$ & $\leq 10$ & $>10$ & \\
\hline Vivier $^{15}$ & $\begin{array}{l}5 \\
(23,8 \%)\end{array}$ & & $\begin{array}{l}13 \\
(61,9 \%)\end{array}$ & & $\begin{array}{l}3 \\
(14,2 \%)\end{array}$ & & 21 \\
\hline Budiyono $^{16}$ & $\begin{array}{l}2 \\
(15,3 \%)\end{array}$ & $\begin{array}{l}1 \\
(7,6 \%)\end{array}$ & $\begin{array}{l}2 \\
(15,3 \%)\end{array}$ & & $\begin{array}{l}3 \\
(23,0 \%)\end{array}$ & $\begin{array}{l}5 \\
(38,4 \%)\end{array}$ & 13 \\
\hline Romli $^{17}$ & $\begin{array}{l}1 \\
(0,5 \%)\end{array}$ & $\begin{array}{l}4 \\
(2,0 \%)\end{array}$ & $\begin{array}{l}6 \\
(3,0 \%)\end{array}$ & $\begin{array}{l}4 \\
(2,0 \%)\end{array}$ & & $\begin{array}{l}5 \\
(2,5 \%)\end{array}$ & 20 \\
\hline Ratnasari $^{18}$ & $\begin{array}{l}3 \\
(12,5 \%)\end{array}$ & $\begin{array}{l}2 \\
(8,3 \%)\end{array}$ & $\begin{array}{l}8 \\
(33,3 \%)\end{array}$ & $\begin{array}{l}5 \\
(20,8 \%)\end{array}$ & $\begin{array}{l}2 \\
(8,3 \%)\end{array}$ & $\begin{array}{l}4 \\
(16,6 \%)\end{array}$ & 24 \\
\hline Mazumdar ${ }^{10}$ & $\begin{array}{l}3 \\
(11,1 \%)\end{array}$ & & $\begin{array}{l}14 \\
(51,8 \%)\end{array}$ & $\begin{array}{l}8 \\
(29,6 \%)\end{array}$ & & $\begin{array}{l}2 \\
(7,4 \%)\end{array}$ & 27 \\
\hline Daneshparvar $^{3}$ & & & $\begin{array}{l}9 \\
(26,4 \%)\end{array}$ & $\begin{array}{l}24 \\
(70,5 \%)\end{array}$ & & $\begin{array}{l}1 \\
(2,9 \%)\end{array}$ & 34 \\
\hline Lo $^{19}$ & & $\begin{array}{l}1 \\
(4,5 \%)\end{array}$ & $\begin{array}{l}8 \\
(36,3 \%)\end{array}$ & $\begin{array}{l}5 \\
(22,7 \%)\end{array}$ & $\begin{array}{l}1 \\
(4,5 \%)\end{array}$ & $\begin{array}{l}7 \\
(31,8 \%)\end{array}$ & 22 \\
\hline Rasoul $^{20}$ & $\begin{array}{l}1 \\
(2,9 \%)\end{array}$ & & $\begin{array}{l}20 \\
(58,8 \%)\end{array}$ & $\begin{array}{l}4 \\
(11,7 \%)\end{array}$ & $\begin{array}{l}6 \\
(17,6 \%)\end{array}$ & $\begin{array}{l}3 \\
(8,8 \%)\end{array}$ & 34 \\
\hline $\mathrm{Li}^{22}$ & & & $\begin{array}{l}42 \\
(53,16 \%)\end{array}$ & $\begin{array}{l}35 \\
(44,30 \%)\end{array}$ & $\begin{array}{l}1 \\
(1,26 \%)\end{array}$ & $\begin{array}{l}1 \\
(1,26 \%)\end{array}$ & 79 \\
\hline Karrari $^{23}$ & & & $\begin{array}{l}66 \\
(44,89 \%)\end{array}$ & $\begin{array}{l}77 \\
(52,38 \%)\end{array}$ & $\begin{array}{l}1 \\
(0,68 \%)\end{array}$ & $\begin{array}{l}3 \\
(2,04 \%)\end{array}$ & 147 \\
\hline Graber $^{24}$ & $\begin{array}{l}1 \\
(2,5 \%)\end{array}$ & & $\begin{array}{l}31 \\
(77,5 \%)\end{array}$ & $\begin{array}{l}6 \\
(15,0 \%)\end{array}$ & $\begin{array}{l}3 \\
(7,5 \%)\end{array}$ & $\begin{array}{l}1 \\
(2,5 \%)\end{array}$ & 40 \\
\hline $\operatorname{Liu}^{25}$ & & & $\begin{array}{l}21 \\
(32,30 \%)\end{array}$ & $\begin{array}{l}42 \\
(64,61 \%)\end{array}$ & $\begin{array}{l}2 \\
(3,07 \% \mathrm{~S})\end{array}$ & & 65 \\
\hline Chen $^{26}$ & & & & $\begin{array}{l}28 \\
(100 \%)\end{array}$ & & & 28 \\
\hline Lewendon $^{27}$ & & & & $\begin{array}{l}20 \\
(95,23 \%)\end{array}$ & $\begin{array}{l}1 \\
(4,76 \%)\end{array}$ & & 21 \\
\hline
\end{tabular}




\begin{tabular}{|c|c|c|c|c|c|c|c|}
\hline \multirow[t]{2}{*}{ Penelitian } & \multicolumn{2}{|c|}{ Buku } & \multicolumn{2}{|c|}{ Jurnal } & \multicolumn{2}{|c|}{ Lain-lain } & \multirow[t]{2}{*}{ Total } \\
\hline & $\leq 10$ & $>10$ & $\leq 10$ & $>10$ & $\leq 10$ & $>10$ & \\
\hline $\begin{array}{l}\text { Shuangxing } \\
\mathrm{Hou}^{4}\end{array}$ & & & $\begin{array}{l}12 \\
(33,33 \%)\end{array}$ & $\begin{array}{l}21 \\
(58,33 \%)\end{array}$ & & $\begin{array}{l}3 \\
(8,33 \%)\end{array}$ & 36 \\
\hline Jusko $^{12}$ & $\begin{array}{l}1 \\
(2.08 \%)\end{array}$ & $\begin{array}{l}5 \\
(10.42 \%)\end{array}$ & $\begin{array}{l}23 \\
(47.92 \%)\end{array}$ & $\begin{array}{l}15 \\
(31.25 \%)\end{array}$ & $\begin{array}{l}4 \\
(8.33 \%)\end{array}$ & & 48 \\
\hline $\operatorname{Min}^{29}$ & $\begin{array}{l}6 \\
(8.96 \%)\end{array}$ & $\begin{array}{l}3 \\
(4.48 \%)\end{array}$ & $\begin{array}{l}37 \\
(55.22 \%)\end{array}$ & $\begin{array}{l}19 \\
(28.36 \%)\end{array}$ & $\begin{array}{l}2 \\
(2.99 \%)\end{array}$ & & 67 \\
\hline Canfield $^{I I}$ & & $\begin{array}{l}4 \\
(8.00 \%)\end{array}$ & $\begin{array}{l}32 \\
(64.00 \%)\end{array}$ & $\begin{array}{l}12 \\
(24.00 \%)\end{array}$ & $\begin{array}{l}2 \\
(4.00 \%)\end{array}$ & & 50 \\
\hline Havens $^{30}$ & & & $\begin{array}{l}6 \\
(22.22 \%)\end{array}$ & $\begin{array}{l}9 \\
(33.33 \%)\end{array}$ & $\begin{array}{l}10 \\
(37.04 \%)\end{array}$ & $\begin{array}{l}2 \\
(7.41 \%)\end{array}$ & 27 \\
\hline $\mathrm{Hou}^{4}$ & & $\begin{array}{l}4 \\
(11.11 \%)\end{array}$ & $\begin{array}{l}19 \\
(52.78 \%)\end{array}$ & $\begin{array}{l}13 \\
(36.11 \%)\end{array}$ & & & 36 \\
\hline Jain $^{8}$ & $\begin{array}{l}1 \\
(1.96 \%)\end{array}$ & & $\begin{array}{l}25 \\
(49.02 \%)\end{array}$ & $\begin{array}{l}16 \\
(31.37 \%)\end{array}$ & $\begin{array}{l}9 \\
(17.65 \%)\end{array}$ & & 51 \\
\hline
\end{tabular}

\section{PEMBAHASAN}

Hasil yang didapat menunjukkan bahwa pajanan timbal dapat mempengaruhi kecerdasan pada anak. Proporsi kadar timbal tertinggi terdapat pada negara Amerika dengan kadar timbal $5-9,9 \mu \mathrm{g} /$ yang dapat menurunkan IQ sebesar 7,4 kali ${ }^{11}$. Hal ini sejalan dengan penelitian terdahulu, diperkirakan terjadi penurunan total IQ sebesar 4.1-5.4 poin pada setiap kenaikan $10 \mathrm{ug} / \mathrm{dl}$ kadar timbal pada darah pada usia 4 tahun, 9 tahun, dan 11 tahun $^{29}$. Penelitian lain menunjukan adanya penurunan nilai IQ sebesar 4.9 poin pada kadar timbal antara 5 sampai dengan $9.9 \mu \mathrm{g} / \mathrm{dL}^{12}$.

Pajanan timbal dapat terjadi disebabkan beberapa faktor, diantaranya faktor emisi kendaraan bermotor, perumahan tua, lingkungan miskin, peleburan aki bekas, saluran air yang tercemar, alat-alat rumah tangga, pendidikan orangtua, kegiatan industri, makanan kaleng, formulasi cat, mainan gigitan bayi, dan debu di rumah. Faktor pemicu pajanan timbal yang paling sering yaitu lingkungan rumah. Anakanak yang memiliki tingkat timbal darah $\geq 10 \mu \mathrm{g}$ / dL dipengaruhi oleh lingkungan rumah yang kurang terawat ${ }^{15}$. Selain itu pendidikan orangtua juga merupakan faktor pemicu pajanan timbal tersering. Berdasarkan uji analisis multivariat pada penelitian sebelumnya, pendidikan orangtua mempengaruhi hubungan timbal dalam darah terhadap tingkat kecerdasan. Dan berpeluang 3,3 kali untuk memiliki tingkat kecerdasan rendah dibandingkan siswa berkadar timbal darah rendah dengan setelah dikontrol variabel pendidikan orang tua ${ }^{16}$.

Setiap hari, tubuh manusia menyerap 100-300 $\mu \mathrm{g}$ timbal lewat saluran pencernaan. Pada orang dewasa sekitar 10\% timbal terserap dalam tubuh, sedangkan persentase konsentrasi timbal yang terserap pada anak-anak adalah $40 \%{ }^{4}$. Pencemaran timbal pada makanan seharusnya dapat dicegah. Debu timbal merupakan sumber utama keracunan timbal pada anak, sehingga makanan yang disajikan juga alat makan harus ditutup untuk mengurangi pajanan dengan debu.

Kenaikan usia juga mempengaruhi kadar timbal dalam darah. Penelitian yang dilakukan di India menunjukan rata-rata kenaikan kadar timbal dalam darah pada anak usia 4 hingga 23 bulan sebesar $14.4 \mu \mathrm{g} / \mathrm{dL}$. Hal ini diperkirakan terjadi karena dengan bertambahnya usia semakin aktif pergerakan anak sementara perkembangan otak belum sempurna ${ }^{8}$. Ini yang mengarahkan mereka pada faktor lain seperti: cat, debu dan makanan.

Sosial ekonomi juga berpengaruh pada pencemaran timbal ${ }^{8}$. Pajanan dari lingkungan 
termasuk debu, pemilihan air minum, kendaraan bermotor, pekerjaan, juga perilaku bersih dan sehat. Jumlah anak dalam keluarga juga termasuk dalam variabel ini. Didapati keluarga dengan status sosial ekonomi tinggi memiliki $\leq$ 2 anak.

Selain kognitif anak, keracunan timbal juga mempengaruhi psikis anak. Depresi, agresi, perilaku abnormal, penarikan diri terhadap lingkungan sosial, dan insomnia menjadi dampak lain terhadap keracunan timbal ${ }^{4}$. Namun patofisiologi pastinya belum diteliti lebih lanjut.

Diperlukannya peran orangtua agar anak-anak tidak rentan terhadap pajanan timbal. Untuk itu orangtua harus mendapat edukasi mengenai bahaya timbal di lingkungannya, mencari tahu sumber paparan, memonitor kadar timbal dalam darah setiap 3 bulan, dan penyuluhan aktivitas masyarakat untuk melakukan pencegahan terhadap paparan timbal yang tinggi ${ }^{31}$. Cara lain untuk mengatasi paparan timbal dalam darah yaitu dengan proses toksik dari paparan plumbum $(\mathrm{Pb})$ dengan pemberian EDTA (Ethylenediaminetetraacetic acid) intravena yang dapat mengikat timbal dalam darah ${ }^{32}$.

\section{KESIMPULAN}

Dari berbagai analisis data dan pembahasan dari temuan-temuan dalam penelitian sebelumnya, maka dapat disimpulkan keracunan timbal dapat mempengaruhi kecerdasan. Adanya timbal dalam darah 5 - 9,9 $\mu \mathrm{g} /$ dapat menurunkan IQ sebesar 7,4 kali. Lingkungan rumah dan pendidikan orangtua menjadi faktor pemicu pajanan timbal tersering. Untuk itu perlu adanya pencegahan pajanan timbal terhadap anak, salah satunya dengan edukasi kepada orangtua mengenai bahaya timbal serta perilaku bersih dan sehat di lingkungan sekitar. Selain itu pemberian EDTA (Ethylenediaminetetraacetic acid) intravena dapat mengatasi pajanan timbal dalam darah.

\section{UCAPAN TERIMA KASIH}

Penulis mengucapkan terima kasih kepada Ibu Fajaria Nurcandra, SKM, M. Epid selaku pembimbing kami dan juga kepada pihak yang telah terlibat.

\section{DAFTAR PUSTAKA}

1. Gusnita D. Pencemaran logam berat timbal (pb) di udara dan upaya penghapusan bensin bertimbal. Ber Dirgant. 2012;13(3):95-101.
2. Muller H, Regard S, Petriccioli N, Kherad O. Traditional medicine: a rare cause of lead poisoning in Western countries. F1000Research. 2013;250:1-5.

3. Daneshparvar M, Mostafavi SA, Jeddi MZ, Yunesian M, Mesdaghinia A, Mahvi $\mathrm{AH}$, et al. The role of lead exposure Attention-Deficit/Hyperactivity Disorder in children: A systematic review. Iran $\mathbf{J}$ Psychiatry. 2016;11(1):1-14.

4. Hou S, Yuan L, Jin P, Ding B, Qin N, Li L, et al. A clinical study of the effects of lead poisoning on the intelligence and neurobehavioral abilities of children. Theor Biol Med Model. 2013;10(1):110.

5. WHO. Global Health Risks: Mortality and burden of disease attributable to selected major risks. Bull World Health Organ [Internet]. 2009;87:646-646. Available from: http://www.who.int/healthinfo/global_bu rden_disease/GlobalHealthRisks_report_ full.pdf

6. 2011 Annual Childhood Lead Florida Lead Poisoning Prevention \& Healthy Homes Program 2011 Annual Childhood Surveillance Report. 2012;(August).

7. Wang S, Zhang J. Blood lead levels in children, China. Environ Res [Internet]. 2006 Jul 1 [cited 2018 Feb 28];101(3):412-8. Available from: https://www.sciencedirect.com/science/ar ticle/pii/S001393510500188X?via\%3Dih $\mathrm{ub}$

8. Jain NB, Hu H. Childhood correlates of blood lead levels in Mumbai and Delhi. Environ Health Perspect. 2006;114(3):466-70.

9. McQuirter JL, Rothenberg SJ, Dinkins G a., Kondrashov V, Manalo M, Todd AC, et al. Lead and Lead Poisoning from Antiquity to Modern Times. Environ Health Perspect [Internet]. 2013;115(1):1-2. Availablefrom: http://www.pubmedcentral.nih.gov/articl erender.fcgi? artid $=1519587 \&$ tool $=$ pmce ntrez\&rendertype $=$ abstract $\% 5 \mathrm{Cnhttp}: / / \mathrm{ba}$ ses.bireme.br/cgi-

bin/wxislind.exe/iah/online/?IsisScript=i ah/iah.xis\&amp;src=google\&amp; base $=$ REPIDISCA\&amp;lang=p\&amp;nextAct ion=lnk\&amp;expr 
10. Mazumdar M, Bellinger DC, Gregas M, Abanilla K, Bacic J, Needleman HL. Low-level environmental lead exposure in childhood and adult intellectual function: a follow-up study. Environ Heal. 2011;10(1):24.

11. Canfield RL, Henderson CR, CorySlechta DA, Cox C, Jusko TA, Lanphear BP. Intellectual Impairment in Children with Blood Lead Concentrations below $10 \mu \mathrm{g}$ per Deciliter. $\mathrm{N}$ Engl J Med [Internet]. 2003;348(16):1517-26. Available from: http://www.nejm.org/doi/abs/10.1056/NE JMoa022848

12. Jusko TA, Henderson CR, Lanphear BP, Cory-Slechta DA, Parsons PJ, Canfield RL. Blood Lead Concentrations < 10 $\mu \mathrm{g} / \mathrm{dL}$ and Child Intelligence at 6 Years of Age. Environ Health Perspect [Internet]. 2008;116(2):243-8. Available from:

http://www.ncbi.nlm.nih.gov/pmc/article $\mathrm{s} / 2235210 /$

13. Kanedi M, Pebrice S, P WA. ANALISIS KADAR TIMBAL ( $\mathrm{Pb}$ ) PADA RAMBUT PEKERJA BENGKEL TAMBAL BAN DAN IKAN MAS DI SEPANJANG JALAN SOEKARNOHATTA BANDAR LAMPUNG SECARA SPEKTROFOTOMETRI SERAPAN ATOM. :91-7.

14. Sanusi, Asih Mahmudah D. yang beredar di daerah Purwokerto, dengan metode spektrofotomeri serapan atom. Dekstruksi yang digunakan adalah dengan dekstruksi basah mengunakan campuran $\mathrm{H} 2 \mathrm{SO} 4$ dan $\mathrm{HNO} 3$. Pengambilan sampel menggunakan metode. 2010;7(3):123-34.

15. Gilmore JH. NIH Public Access. North. 2008;29(10):1883-9.

16. Budiyono, Haryanto B, Hamonangan E, Hindratmo B. Korelasi Timbal Dalam Darah Dan Tingkat Kecerdasan ( Majemuk ) Siswa Sekolah Dasar Di Sekitar Peleburan Aki Correlation Blood Lead Levels and Inteligence Levels Among Elementary School Students Living At Surrounding Used Battery Smelter in the Regency of. Ecolab. 2016;10(1):41-7.

17. Romli M, Setiani O. Hubungan Kadar
Plumbum ( $\mathrm{Pb}$ ) Dalam Darah dengan Prestasi Belajar Pada Anak Sekolah di SDN Grinting 01 Kecamatan Bulakamba Kabupaten Brebes. 2016;15(2):36-41.

18. Ratnasari DM, Sitaresmi MN, Mulyani NS. Hubungan Kadar Timbal Darah dengan Tingkat Inteligensi Anak. 2016;18(1):265-9.

19. Lo YC, Dooyema CA, Neri A, Durant J, Jefferies T, Medina-Marino A, et al. Childhood lead poisoning associated with gold ore processing: A village-level Investigation-Zamfara State, Nigeria, October-November 2010. Environ Health Perspect. 2012;120(10):1450-5.

20. Holmer I. Original article. 1989;15(1):58-65.

21. Lin S, Wang X, Yu ITS, Tang W, Miao $\mathrm{J}$, Li J, et al. Environmental lead pollution and elevated blood lead levels among children in a rural area of china. Am J Public Health. 2011;101(5):83441.

22. Li Y, Qin J, Wei X, Li C, Wang J, Jiang $M$, et al. The risk factors of child lead poisoning in China: A meta-analysis. Int J Environ Res Public Health. 2016;13(3).

23. Karrari P, Mehrpour O, Abdollahi M. A systematic review on status of lead pollution and toxicity in Iran; Guidance for preventive measures. DARU, J Pharm Sci. 2012;20(1):1-17.

24. Graber LK, Asher D, Anandaraja N, Bopp RF, Merrill K, Cullen MR, et al. Childhood lead exposure after the phaseout of leaded gasoline: An ecological study of school-age children in Kampala, Uganda. Environ Health Perspect. 2010;118(6):884-9.

25. Liu J, Li L, Wang Y, Yan C, Liu X. Impact of Low Blood Lead Concentrations on IQ and School Performance in Chinese Children. PLoS One. 2013;8(5).

26. Chen AM, Dietrich KN, Ware JH, Radcliffe J, Rogan WJ. IQ and blood lead from 2 to 7 years of age: Are the effects in older children the residual of high blood lead concentrations in 2-yearolds? Environ Health Perspect [Internet]. 2005;113(5):597-601. Available from: http://ehp.niehs.nih.gov/members/2005/7 
625/7625.pdf

27. Lewendon G, Kinra S, Nelder R, Cronin T. Should children with developmental and behavioural problems be routinely screened for lead? Arch Dis Child. 2001;85(4):286-8.

28. Shah KK, Oleske JM, Gomez HF, Davidow AL, Bogden JD. Blood Lead Concentrations of Children in the United States: A Comparison of States Using Two Very Large Databases. J Pediatr [Internet]. 2017;185:218-23. Available from:

http://linkinghub.elsevier.com/retrieve/pi i/S0022347617301695

29. Min MO, Singer LT, Kirchner HL, Minnes S, Short E, Hussain Z, et al.
Cognitive development and low-level lead exposure in poly-drug exposed children. Neurotoxicol Teratol. 2009;31(4):225-31.

30. Havens D, Pham M, Karr C, Daniell W. Blood Lead Levels and Risk Factors for Lead Exposure in a Pediatric Population in Ho Chi Minh City, Vietnam. Int J Environ Res Public Health [Internet]. 2018;15(2):93. Available from: http://www.mdpi.com/1660$4601 / 15 / 1 / 93$

31. Betts KS. Forum cdc Updates Guidelines for children' s lead exposure. Environ Health Perspect. 2012;120(7):A268.

32. Syahrizal D. Pengaruh plumbum $(\mathrm{Pb})$ terhadap perkembangan anak. 2009; 